\title{
THE EFFECT OF PRICES, PRODUCT REVIEWS, EASE OF USE, AND SECURITY OF TRANSACTIONS ON PURCHASING DECISIONS ONLINE IN SHOPEE
}

\section{PENGARUH HARGA, ULASAN PRODUK, KEMUDAHAN PENGGUNAAN, DAN KEAMANAN TRANSAKSI TERHADAP KEPUTUSAN PEMBELIAN SECARA ONLINE DI SHOPEE}

\author{
(Studi Kasus Mahasiswa Fakultas Ekonomi Manajemen \\ Universitas Muhammadiyah Bengkulu)
}

\author{
Homami Rahayu 1); Adi Sismanto 2); Tezar Arianto3) \\ 1)Study Program of Management, Faculty of Economic, Universitas Muhammadiyah Bengkulu \\ 2,3) Department of Management, Faculty of Economic, Universitas Muhammadiyah Bengkulu
}

Email: 1)hamamirahayu23@gmail.com, ${ }^{2)}$ Adisismanto59@gmail.com, ${ }^{3}$ Tezararianto@umb.ac.id

\begin{abstract}
How to Cite :
Rahayu H., Sismanto, A., Arianto, T. (2020). Pengaruh Harga, Ulasan Produk, Kemudahan Penggunaan, Dan Keamanan Transaksi Terhadap Keputusan Pembelian Secara Online Di Shopee (Studi Kasus Mahasiswa Fakultas Ekonomi Manajemen Universitas Muhammadiyah Bengkulu). Bima Journal: Bussines Managemet and Accounting, 1(1).
\end{abstract}

\section{ARTICLE HISTORY}

Received [11-01-2020]

Revised [15-01-2020]

Accepted [17-02-2020]

\section{KEYWORDS}

Product, Price, Promotion, Place Purchase Decisio

This is an open access article under the CCBY-SA license

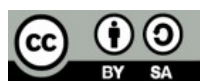

\section{ABSTRAK}

Penelitian ini bertujuan untuk mengetahui pengaruh harga, ulasan produk, kemudahan penggunaan, dan keamanan transaksi terhadap keputusan pembelian secara online di Shopee (studi kasus mahasiswa Fakultas Ekonomi Manajemen Universitas Muhammadiyah Bengkulu). Penelitian ini menggunakan sampel berjumlah 105 orang responden dengan menggunakan teknik purposive sampling. Teknik pengumpulan data dengan menggunakan observasi dan kuesioner. Teknik analisis yang digunakan adalah regresi tanggapan responden, regresi linier berganda, analisis koefisien korelasi dan koefisien determinasi $\left(R^{2}\right)$. Penelitian ini menggunakan uji validitas, uji reliabilitas, dan uji asumsi klasik dilanjutkan dengan pengujian hipotesis. Berdasarkan hasil analisis regresi linier berganda, dengan hasil penelitian harga berpengaruh terhadap keputusan pembelian online di Shopee. Di buktikan dengan hasil uji t menunjukkan $t_{\text {hit }}>t_{a / 2}(2.022>0.1982)$ dan (sig $a=0.046<0.050$ ), ini berarti $\mathrm{H}_{0}$ ditolak dan $\mathrm{H}_{\mathrm{a}}$ di terima. Ulasan Produk berpengaruh positif dan signifikan secara parsial terhadap keputusan pembelian online di Shopee, hal ini dibuktikan dengan hasil uji t yang menunjukkan nilai yaitu $t_{h i t}>t_{a / 2}(2.212>0.1982)$ dan ( $\operatorname{sig} a=0.029<0.050$ ), ini berarti $\mathrm{H}_{0}$ ditolak dan $\mathrm{H}_{\mathrm{a}}$ di terima. Kemudahan Penggunaan berpengaruh positif dan signifikan secara parsial terhadap keputusan pembelian online di Shopee, hal ini dibuktikan dengan hasil uji t yang menunjukkan nilai yaitu $t_{h i t}>t_{a / 2}(2.113>0.1982)$ dan (sig $\left.a=0.037<0.050\right)$, ini berarti $\mathrm{H}_{0}$ ditolak dan $\mathrm{H}_{\mathrm{a}}$ di terima. Keamanan Transaksi berpengaruh positif dan signifikan secara parsial terhadap keputusan pembelian online di Shopee, hal ini dibuktikan dengan hasil uji t yang menunjukkan nilai yaitu $\mathrm{t}_{\text {hit }}>\mathrm{t}_{\mathrm{a} / 2}(2.955>0.1982)$ dan ( $\left.\operatorname{sig} a=0.004<0.050\right)$, ini berarti $\mathrm{H}_{0}$ ditolak dan $\mathrm{H}_{\mathrm{a}}$ di terima. Harga $\left(X_{1}\right)$ Ulasan Produk $\left(X_{2}\right)$, Kemudahan Penggunaan $\left(X_{3}\right)$ dan Keamanan Transaksi $\left(X_{4}\right)$ secara bersama-sama berpengaruh terhadap Keputusan Pembelian $(Y)$ online di Shopee, hal ini dibuktikan dengan uji $F$ menunjukkan nilai $t_{\text {hitung }}>t_{\text {tabel, }}$ yaitu $\left(6.392>2.69\right.$ ) dan ( $\operatorname{sig} a=0.000<0.05$ ) ini berarti $\mathrm{H}_{0}$ ditolak dan $\mathrm{H}_{a}$ diterima. 


\section{PENDAHULUAN}

Pada era globalisasi sekarang ini, internet menjadi semakin canggih dan terus berkembang. Teknologi ini sangat menguntungkan bagi banyak orang karena memiliki banyak manfaat. Kalau dulu internet hanya dimanfaatkan untuk mencari data, sekarang internet dapat dimanfaatkan untuk banyak hal, salah satunya adalah untuk menjalankan usaha. Di Indonesia, penggunaan internet sudah tidak asing lagi. Menurut Ketua Umum APJII (Asosiasi Penyelenggara Jasa Internet Indonesia) Jamalul Izza pada tanggal 23 Agustus 2016, pengguna internet di Indonesia mencapai 133 juta pengguna. Angka ini meningkat dibanding dengan tahun 2015, yang mana jumlah pengguna internet di Indonesia berjumlah 88, 1 juta pengguna. (Rachmatunnisa, 2016, para. 3). Berdasarkan data sensus penduduk yang digelar Badan Pusat Statistik (BPS) tahun 2015, jumlah penduduk Indonesia sekitar 255 juta orang (Putra, 2016, para. 4). Dari data-data tersebut, dapat disimpulkan bahwa lebih dari setengah jumlah penduduk di Indonesia sudah mengenal dan menggunakan internet. E-commerce adalah sebuah konsep yang menggambarkan suatu proses pembelian dan penjualan pertukaran jasa, produk, dan informasi melalui jaringan komputer termasuk internet (Turban, King, Lee, Liang \& Turban, 2012, p. 38).

Harga yang ada di Shopee terkadang juga menjebak konsumen dan kurangnya informasi atau pun ulasan yang kurang jelas mengenai produk tersebut jadi banyak para konsumen merasa tertipu dan kecewa. Sekarang pihak Shopee juga tidak menyediakan fasilitas free ongkir yang biasanya didapatkan satu minggu 3 kali checkout free tanpa ongkos kirim. Namun pihak Shopee sekarang menggantikannya dengan voucher gratis ongkir dimana voucher ini bukan voucher gratis ongkir sesuai namanya tapi ini voucher pemotongan ongkir Rp 20.000 satu voucher dan satu kali checkout.

\section{LANDASAN TEORI}

\section{Keputusan Pembelian}

Turban et al. (2004), Katawetawaraks dan Wang (2011) menjelaskan bahwa belanja online adalah kegiatan pembelian produk (baik barang ataupun jasa) melalui media internet. Kegiatan belanja online meliputi kegiatan Business to Business (B2B) maupun Business to Consumers (B2C). Salah satu manfaat dalam belanja online adalah calon pembeli dapat melihat ter-lebih dahulu (produk) yang akan dibelinya melalui web yang ditawarkan oleh penjual.

Kegiatan ini sering di sebut dengan searching. Belanja online dapat dilakukan dengan cara melakukan window shopping online pada web yang dituju. Kemudian, pembeli dapat mengeklik barang yang diinginkan. Setelah itu pembeli kemudian dibawa kepada jendela yang menampilkan tata cara pembayaran yang disepakati dan kemudian setelah nominal uang ditransfer, maka penjual akan mengirim barang melalui jasa pos dan sebagainya. Pembayaran dapat dilakukan baik menggunakan kartu debit, kartu kredit, PayPal, memotong pulsa pelanggan (untuk transaksi lewat HP), cek maupun COD (Cash On Delivery) yaitu pembayaran yang dilakukan ketika barang telah dikirim oleh penjual. Seperti yang dinyatakan oleh Kotler dan Keller (2009:184) terdapat lima tahapan dalam konsep proses keputusan pembelian kosumen sebagai berikut : 
Gambar 1. Proses Keputusan Pembelian

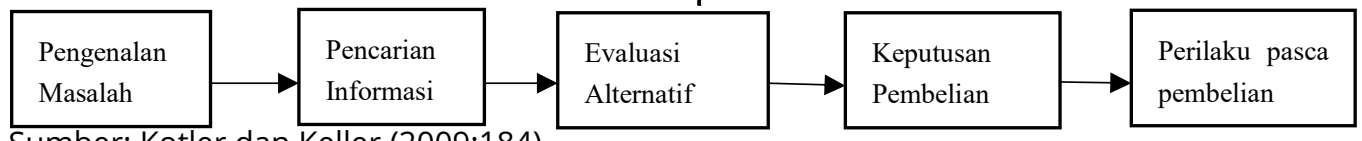

Sumber: Kotler dan Keller (2009:184)

Indikator Keputusan Pembelian

Menurut Kotler dan Amstrong (2008) terdapat empat indikator keputusan pembelian

1. Pembeli memutuskan untuk membeli produk di Shopee karena faktor harga.

2. Pembeli memutuskan untuk membeli produk di Shopee karena faktor ulasan produk.

3. Pembeli memutuskan untuk membeli produk di Shopee karena faktor kemudahan penggunaan

4. Pembeli memutuskan untuk membeli produk di Shopee karena faktor keamanan transaksi

\section{Harga}

Menurut Philip Kotler (2005) "Harga adalah jumlah uang yang harus dibayar pelanggan untuk produk itu." Sedangkan menurut Simamora (2003:574) "Harga adalah jumlah uang yang dibebankan atau dikenakan atas sebuah produk atau jasa." .Harga adalah nilai suatu barang atau jasa yang diukur dengan jumlah uang yang dikeluarkan oleh pembeli untuk mendapatkan sejumlah kombinasi dan barang atau jasa berikut pelayanannya. Harga menurut Jerome Mc Cartgy (2002), harga adalah apa yang dibebabankan untuk sesuatu. Harga merupakan faktor penentu utama permintaan konsumen. Engel (2001) mendefinisikan harga sebagai sejumlah uang yang dibutuhkan untuk mendapatkan sejumlah kombinasi dari produk dan pelayanannya.

\section{Indikator Harga}

Menurut Simamora (2003:200), Adapun indikator dari harga (Swashta, 1997, h.246, Winardi, 1992, h.320) sebagai berikut :

1. Harga Produk Bersaing

2. Diskon (potongan pembelian)

3. Harga Terjangkau

4. Harga Sebanding Dengan Kualitas Produk

\section{Ulasan Produk}

Vinodhini, et al., 2012 Pengertian ulasan bermakna tinjauan, ringkasan dari beberapa sumber baik buku, film, berita dan yang lainnya. Secara harfiah, ulasan ini difungsikan sebagai salah satu hal untuk meninjau karya untuk mengetahui kualitas, kelebihan serta kekurangan yang dimiliki oleh karya tersebut. Menurut (Lackermair, Kailer, \& Kanmaz, 2013, p. 2) ulasan produk adalah sebuah fitur yang terdapat di Shopee yang digunakan untuk mendeskripsikan keunggulan atau kelemahan sebuah produk. Terdapat empat indikator ulasan produk Kesadaran atau Awareness pembeli sadar akan adanya fitur ulasan produk yang ada di Shopee dan menggunakan informasi tersebut dalam proses seleksi. 


\section{Indikator Ulasan Produk}

Terdapat empat indikator ulasan produk. (Lackermair, Kailer, \& Kanmaz, 2013, p. 2).

1. Kesadaran atau Awareness pembeli sadar akan adanya fitur ulasan produk yang ada di Shopee dan menggunakan informasi tersebut dalam proses seleksi.

2. Frekuensi atau Frequency pembeli sering menggunakan fitur ulasan produk di Shopee sebagai sumber informasi.

3. Perbandingan atau Comparison sebelum membeli, pembeli membaca ulasan produk yang akan dibeli, yang terdapat di Shopee satu demi satu dan membandingkan ulasan-ulasan tersebut.

4. Pengaruh atau Effect fitur ulasan produk di Shopee memberikan pengaruh terhadap seleksi produk.

\section{Kemudahan Penggunaan}

Davis dalam Nasution (2004: 5) mendefinisikan kemudahan penggunaan (ease of use) sebagai suatu tingkatan dimana seseorang percaya bahwa komputer dapat dengan mudah dipahami. Konsep ini mencakup kejelasan tujuan teknologi dan kemudahan penggunaan sistem untuk tujuan yang sesuai dengan keinginan pemakai. (Vankatesh \& Davis, 2000) Kemudahan penggunaan kemungkinan akan menyebabkan penggunaan teknologi yang lebih dalam pengaplikasiannya, sedangkan jika dirasa sulit penggunaannya akan berdampak pada pengulangan.

\section{Indikator Keamanan Transaksi}

Indikator keamanan transaksi menurut Raman Arasu dan Viswanathan A. (2011), indikator kemanan transaksi meliputi:

1. Jaminan Keamanan

2. Kerahasiaan Data

3. Jaminan Kesesuaian Produk

\section{Kerangka Penelitian}

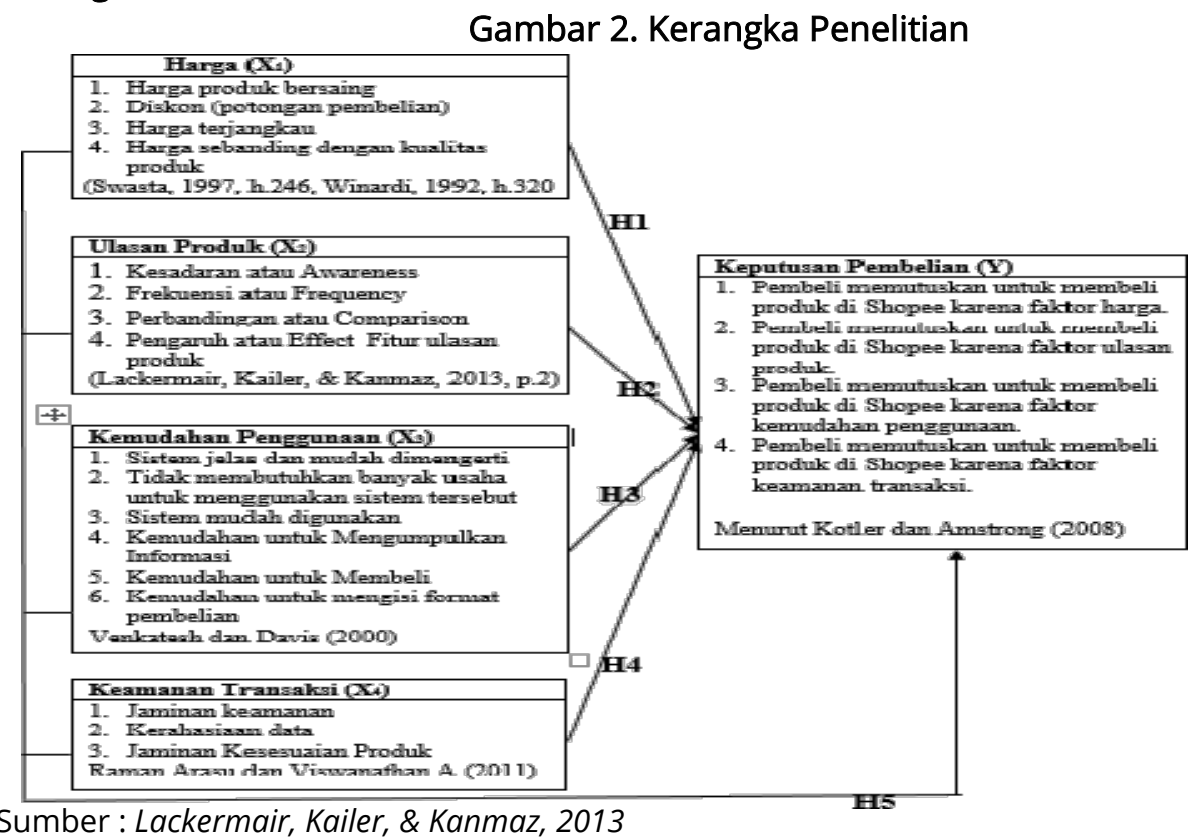




\section{Hipotesis}

Menurut Sugiyono, (2005:54) Hipotesis merupakan jawaban sementara terhadap rumusan masalah penelitian. Adapun hipotesis dalam penelitian ini adalah:

$\mathrm{H}_{1}$ : Diduga harga berpengaruh signifikan secara parsial terhadap keputusan pembelian online di Shopee pada Mahasiswi Fakultas Ekonomi Manajemen Universitas Muhammadiyah Bengkulu

$\mathrm{H}_{2}$ : Diduga ulasan produk berpengaruh signifikan secara parsial terhadap keputusan pembelian online di Shopee pada Mahasiswi Fakultas Ekonomi Manajemen Universitas Muhammadiyah Bengkulu

$\mathrm{H}_{3}$ : Diduga kemudahan penggunaan berpengaruh signifikan secara parsial terhadap keputusan pembelian online di Shopee pada Mahasiswi Fakultas Ekonomi Manajemen Universitas Muhammadiyah Bengkulu

$\mathrm{H}_{4}$ : Diduga keamanan transaksi berpengaruh signifikan secara parsial terhadap keputusan pembelian online di Shopee pada Mahasiswi Fakultas Ekonomi Manajemen Universitas Muhammadiyah Bengkulu

$\mathrm{H}_{5}$ : Diduga harga, ulasan produk, kemudahan penggunaan dan keamanan transaksi berpengaruh secara signifikan secara simultan terhadap keputusan pembelian online di Shopee pada Mahasiswi Fakultas Ekonomi Manajemen Universitas Muhammadiyah Bengkulu.

\section{Jenis Penelitian}

\section{METODE PENELITIAN}

Jenis penelitian ini merupakan peneltitian deskriptif kuantitatif. Menurut Fauzi (2009:19) penelitian deskriptif yaitu menganalisis dan menyajikan fakta secara sistematik sehingga dapat lebih mudah di pahami dan di simpulkan. Menurut Mardalis (2009:26) penelitian deskriptif bertujuan untuk mendeskripsikan, mencatat, menganalisis, dan menginterprestasikan kondisi-kondisi yang sekarang ini terjadi atau ada.

\section{Populasi}

Menurut Sugiyono (2013:90) menyatakan bahwa populasi adalah wilayah generalisasi yang terdiri atas objek atau yang mempunyai kualitas dan karakteristik tertentu yang ditetapkan oleh peneliti untuk dipelajari dan kemudian ditarik kesimpulannya. Populasi dalam penelitian ini adalah mahasiswa Universitas Muhammadiyah Bengkulu Fakultas Ekonomi Prodi Manajemen yang pernah berbelanja online di Shopee yang jumlahnya tidak diketahui (infinite).

\section{Sampel}

Sampel adalah bagian dari jumlah dan karakteristik yang dimiliki oleh populasi tersebut (Sugiyono, 2010:91). Teknik pengambilan sampel yang digunakan dalam penelitian ini adalah dengan purposive sampling, yaitu teknik penentuan sampel dengan pertimbangan tertentu (Sugiyono, 2010:218). Kriteria yang digunakan dalam penelitian ini yaitu laki-laki dan perempuan yang sudah pernah berbelanja di Shopee. Penentuan jumlah sampel yang representative menurut Hair 
et al. (1995 dalam Kiswati 2010) adalah tergantung pada jumlah indikator dikali 5 sampai 10. Jumlah sampel dalam penelitian ini adalah:

Sampel = jumlah indikator $\times 5$

$21 \times 5=105$

Berdasarkan perhitungan di atas di dapat untuk sampel minimum menggunakan 105 sampel responden.

Jumlah seluruh mahasiswa aktif fakultas ekonomi manajemen Universitas Muhammadiyah Bengkulu berjumlah 1136 mahasiswa. Cara pengukuran sampel adalah berdasarkan proporsi fakultas, antara lain :

$$
\text { Sampel }=\frac{\text { jwmlah per angkatan }}{\text { jumlah seluruh mahasiswa }} \times 100 \%
$$

Tabel 1. Data Mahasiswa Aktif

\begin{tabular}{|c|c|c|c|c|c|}
\hline No & Angkatan & Jumlah Mahasiswa & Persentase Jumlah Mahasiswa & Responden & Sampel penelitian \\
\hline 1 & 2014 & 36 & $3 \%$ & 105 & 5 \\
\hline 2 & 2015 & 214 & $16 \%$ & 105 & 18 \\
\hline 3 & 2016 & 299 & $26 \%$ & 105 & 25 \\
\hline 4 & 2017 & 321 & $32 \%$ & 105 & 34 \\
\hline 5 & 2018 & 266 & $23 \%$ & 105 & 23 \\
\hline \multicolumn{2}{|l|}{ JUMLAH } & 1136 & & & 105 \\
\hline
\end{tabular}

\section{Sumber : Prodi Ekonomi Manajemen UMB}

Uji Instrument Penelitian

Uji instrument ini dilakukan untuk menguji tingkat validitas dan reliabilitas variabel penelitian, teknik pengujian tersebut sebagai berikut :

Uji Validitas

Menurut Sugiyono (2010:121) Uji Validitas adalah ketetapan antara data yang terkumpul dengan data yang sesungguhnya terjadi pada objek yang diteliti. Dasar pengambilan keputusan valid atau tidaknya pernyataan dinyatakan oleh Sugiyono (2010:126) :

Bila : $\quad r$ hitung $>$ r table 0,30, berarti pernyataan tersebut dinyatakan valid.

$r$ hitung < r table 0,30, berarti pernyataan tersebut dinyatakan tidak valid.

Untuk mengetahui valid tidaknya pernyataan dilakukan uji validitas dengan rumus Karl Pearson Correlation product, dengan rumus sebagai berikut :

Dimana :

$$
r=\frac{n \Sigma x y-\Sigma x \cdot \Sigma y}{\sqrt{\left[n \sum x^{2}-(\Sigma x)^{2}\right]\left[n \Sigma y^{2}-(\Sigma y)^{2}\right]}} \quad \cdots \ldots \ldots . . . . . \text { Sugiyono }(2010: 126)
$$

$r=$ Koefisien korelasi product moment

$\mathrm{x}=$ Skor masing-masing pernyataan

$\mathrm{y}=$ Total skor item-item pernyataan

$\mathrm{n}=$ Banyak data atau responden

\section{Uji Reliabilitas}

Hasil penelitian dikatakan reliable, bila terdapat kesamaan data dalam waktu yang berbeda (Sugiyono, 2010:121). Pengujian reliabilitas instrument dengan rentang skor 1-4 menggunakan rumus Cronbach's Alpha, dengan rumus sebagai berikut : $\quad r N=\left[\frac{K}{(k-1)}\right]\left[\frac{\Sigma \beta}{a \mathbf{1}^{2}}\right]$ Sugiyono (2010:121)

Keterangan :

$\mathrm{n}=$ Reliabilitas Instrument 
ISSN:

$\mathrm{k}=$ Banyak butir pernyataan atau banyak soal

$\sum a b^{2}=$ Jumlah varian butir

a $1^{2}=$ Jumlah varian total

Jika koefisien Croncbach's Alpha kurang dari 0,6 maka mengindikasikan relibilitas item-item dalam pertanyaan yang buruk. Jika koefisien Croncbach Alpha dengan range 0,7 dapat diterima.

Teknik Analisis Regresi Linier Berganda

Analisis kuantitatif dengan menggunakan alat analisis regresi berganda adalah suatu analisis yang digunakan oleh peneliti, bila peneliti bermaksud meramalkan bagaimana keadaan (naik turunnya) variabel dependen, bila dua variabel atau lebih variabel sebagai factor predictor, sebagaimana di kutip dari (Sugiyono, 2010:192).

Adapaun bentuk persamaan regresi linier berganda yang digunakan adalah sebagai berikut :

$Y=a+b_{1} X_{1}+b_{2} X_{2}+b_{3} X_{3}+b_{4} X_{4}+e$ Sugiyono, (2010:277)

Keterangan :

$\mathrm{Y}=$ Keputusan Pembelian

$\mathrm{a}=$ Konstanta

$\mathrm{X}_{1}=$ Harga

$\mathrm{X}_{2}=$ Ulasan Produk

$X_{3}=$ Kemudahan Penggunaan

$\mathrm{X}_{4}=$ Keamanan Bertransaksi

$b_{1}, b_{2}, b_{3}, b_{4}=$ Besaran koefisien regresi dari masing-masing

Uji Hipotesis

Hipotesis Parsial (t)

Uji hipotesis ini dilakukan dengan cara membandingkan nilai t hitung dengan nilai t tabel tingkat keyakinan $95 \%$ atau $\alpha=0,05$. Uji - t digunakan untuk menguji apakah variabel bebas mempunyai pengaruh yang signifikan terhadap nilai variabel terikat dengan rumus hipotesis sebagai berikut:

$$
\begin{aligned}
& \mathrm{t}=\frac{\mathrm{bi}}{\mathrm{sbi}} \\
& \text { Keterangan : } \\
& \mathrm{t}=\text { Nilai................... Sugiyono }(2010: 153) \\
& \mathrm{bi}=\text { Koefisien Regresi } \\
& \text { sbi = Standar Error } \\
& \text { Dengan langkah pengujian sebagai berikut : }
\end{aligned}
$$

\section{Hipotesis Simultan (F)}

Uji F digunakan untuk melihat secara bersama-sama signifikansi pengaruh variabel bebas yaitu harga, ulasan produk, kemudahan penggunaan dan keamanan transaksi, sebagai variabel independen terhadap keputusan pembelian sebagai variabel dependen. Pada taraf keyakinan $95 \%$ atau $\boldsymbol{\alpha}=0,05$. Dan berdasarkan perbandingan nilai $F_{\text {hitung }}$ dengan $F_{\text {tabel }}$ Dengan rumus sebagai berikut :

$$
\text { F.test }=\frac{R^{2} /(k-1)}{(1-R) /(n-k)}
$$




\section{HASIL DAN PEMBAHASAN}

Hasil

Uji Validitas dan Reliabilitas

Tabel 2. Uji Validitas

\begin{tabular}{|c|c|c|c|c|}
\hline Variabel & Item Pernyataan & $\begin{array}{l}\text { Corrected Item } \\
\text { Pernyataan Total } \\
\text { Correlation }\end{array}$ & R.Tabel & Keterangan \\
\hline \multirow{4}{*}{$\begin{array}{l}\text { Harga } \\
\left(X_{1}\right)\end{array}$} & 1 & 0.915 & 0.30 & Valid \\
\hline & 2 & 0.872 & 0.30 & Valid \\
\hline & 3 & 0.729 & 0.30 & Valid \\
\hline & 4 & 0.882 & 0.30 & Valid \\
\hline \multirow{5}{*}{$\begin{array}{l}\text { Ulasan Produk } \\
\left(\mathrm{X}_{2}\right)\end{array}$} & 1 & 0.914 & 0.30 & Valid \\
\hline & 2 & 0.794 & 0.30 & Valid \\
\hline & 3 & 0.906 & 0.30 & Valid \\
\hline & 4 & 0.803 & 0.30 & Valid \\
\hline & 5 & 0.923 & 0.30 & Valid \\
\hline \multirow{7}{*}{$\begin{array}{l}\text { Kemudahan } \\
\text { Penggunaan } \\
\left(X_{3}\right)\end{array}$} & 1 & 0.827 & 0.30 & Valid \\
\hline & 2 & 0.782 & 0.30 & Valid \\
\hline & 3 & 0.859 & 0.30 & Valid \\
\hline & 4 & 0.696 & 0.30 & Valid \\
\hline & 5 & 0.809 & 0.30 & Valid \\
\hline & 6 & 0.840 & 0.30 & Valid \\
\hline & 7 & 0.817 & 0.30 & Valid \\
\hline \multirow{4}{*}{$\begin{array}{l}\text { Keamanan Transaksi } \\
\left(\mathrm{X}_{4}\right)\end{array}$} & 1 & 0.718 & 0.30 & Valid \\
\hline & 2 & 0.764 & 0.30 & Valid \\
\hline & 3 & 0.727 & 0.30 & Valid \\
\hline & 4 & 0.646 & 0.30 & Valid \\
\hline \multirow{4}{*}{$\begin{array}{l}\text { Keputusan } \\
\text { Pembelian (Y) }\end{array}$} & 1 & 0.814 & 0.30 & Valid \\
\hline & 2 & 0.788 & 0.30 & Valid \\
\hline & 3 & 0.887 & 0.30 & Valid \\
\hline & 4 & 0.869 & 0.30 & Valid \\
\hline
\end{tabular}

Sumber data: output SPSS yang diolah, 2019

Dari tabel diatas dapat dilihat nilai Corrected Item Total Corelation atau nilai untuk masing-masing variabel $>r$ tabel (0.30). ini menunjukkan bahwa item dari setiap pertanyaan kuesioner masing-masing variabel tersebut adalah valid dan layak untuk digunakan dalam penelitian ini. Artinya item dari setiap pernyataan tersebut mampu mengukur dan menjelaskan variabelnya secara tepat.

Tabel 3. Uji Reliabilitas

\begin{tabular}{|c|c|c|c|}
\hline Variabel & Pernyataan & Cronbach's Alpha & Keterangan \\
\hline \multirow{4}{*}{$\begin{array}{l}\text { Harga } \\
\left(X_{1}\right)\end{array}$} & 1 & \multirow{4}{*}{0.846} & \multirow{4}{*}{ Reliabel } \\
\hline & 2 & & \\
\hline & 3 & & \\
\hline & 4 & & \\
\hline \multirow{5}{*}{$\begin{array}{l}\text { Ulasan Produk } \\
\left(\mathrm{X}_{2}\right)\end{array}$} & 1 & \multirow{5}{*}{0.919} & \multirow{5}{*}{ Reliabel } \\
\hline & 2 & & \\
\hline & 3 & & \\
\hline & 4 & & \\
\hline & 5 & & \\
\hline \multirow{7}{*}{$\begin{array}{l}\text { Kemudahan } \\
\text { Penggunaan } \\
\left(X_{3}\right)\end{array}$} & 1 & \multirow{7}{*}{0.909} & \multirow{7}{*}{ Reliabel } \\
\hline & 2 & & \\
\hline & 3 & & \\
\hline & 4 & & \\
\hline & 5 & & \\
\hline & 6 & & \\
\hline & 7 & & \\
\hline \multirow{4}{*}{ Keamanan Transaksi $\left(\mathrm{X}_{4}\right)$} & 1 & \multirow{4}{*}{0.677} & \multirow{4}{*}{ Reliabel } \\
\hline & 2 & & \\
\hline & 3 & & \\
\hline & 4 & & \\
\hline \multirow{4}{*}{$\begin{array}{l}\text { Keputusan Pembelian } \\
\text { (Y) }\end{array}$} & 1 & \multirow{4}{*}{0.860} & \multirow{4}{*}{ Reliabel } \\
\hline & 2 & & \\
\hline & 3 & & \\
\hline & 4 & & \\
\hline
\end{tabular}


Tabel diatas menunjukkan hasil pengujian terhadap masing-masing variabel, dapat disimpulkan bahwa semua variabel menunjukkan sebagai suatu ukuran yang reliabel, karena masing-masing variabel memiliki Cronbach's Alpha $>0,60$. Hal ini berarti instrumen penelitian (kuesioner) memiliki hasil yang reliabel (konsisten) sehingga layak untuk digunakan dalam penelitian.

\section{Analisis Persamaan Regresi Linier Berganda}

Analisis persamaan regresi linier berganda digunakan dalam penelitian ini dengan tujuan untuk mengetahui ada tidaknya pengaruh variabel bebas terhadap variabel terikat. Perhitungan statistik dalam analisis regresi linear berganda yang digunakan dalam penelitian ini adalah dengan menggunakan bantuan program komputer SPSS for Windows versi 16. Ringkasan hasil pengolahan data dengan menggunakan program SPSS tersebut terdapat pada tabel berikut ini:

Tabel 4. Coefficients

\begin{tabular}{|c|c|c|c|c|c|}
\hline \multirow[b]{2}{*}{ Model } & \multicolumn{2}{|c|}{ Unstandardized Coefficients } & \multirow{2}{*}{\begin{tabular}{|c} 
Standardized Coefficients \\
Beta \\
\end{tabular}} & \multirow[b]{2}{*}{$\mathrm{t}$} & \multirow[b]{2}{*}{ Sig. } \\
\hline & B & Std. Error & & & \\
\hline (Constant) & .632 & 3.175 & & .199 & .843 \\
\hline Harga & .201 & .099 & .183 & 2.022 & .046 \\
\hline ulasanproduk & .142 & .064 & .203 & 2.212 & .029 \\
\hline kemudahanpenggunaan & .117 & .055 & .191 & 2.113 & .037 \\
\hline keamanantransaksi & .344 & .116 & .273 & 2.955 & .004 \\
\hline
\end{tabular}

a. Dependent Variable: keputusanpembelian

Sumber : Hasil Penelitian SPSS 2019

Dari perhitungan menggunakan SPSS versi 16 for windows didapatkan persamaan regresinya adalah $: Y=0.632+0.201 X_{1}+0.142 X_{2}+0.117 X_{3}+0.344 X_{4}$

Angka tersebut masing-masing secara ekonomis dapat dijelaskan sebagai berikut :

1. Nilai konstanta 0.632 mempunyai arti bahwa apabila variabel harga $\left(X_{1}\right)$, ulasan produk $\left(X_{2}\right)$, kemudahan penggunaan $\left(X_{3}\right)$, keamanan transaksi $\left(X_{4}\right)$ terhadap keputusan pembelian (Y), sama dengan nol maka variabel keputusan pembelian akan tetap yaitu 0.632. Hasil ini berlaku saat dilaksanakannya penelitian.

2. Koefisien regresi variabel harga $\left(X_{1}\right)$ sebesar 0.201 mempunyai makna bahwa apabila harga $\left(X_{1}\right)$ ditingkatkan satu satuan, maka akan meningkatkan keputusan pembelian (Y) pada mahasiswa Universitas Muhammadiyah Bengkulu Fakultas Ekonomi Manajemen sebesar 0.201 dengan asumsi variabel harga, ulasan produk, kemudahan penggunaan, dan keamanan transaksi.

3. Koefisien regresi variabel ulasan produk $\left(X_{2}\right)$ sebesar 0.142 mempunyai makna bahwa apabila ulasan produk $\left(X_{2}\right)$ ditingkatkan satu satuan, maka akan meningkatkan keputusan pembelian (Y) pada mahasiswa Universitas Muhammadiyah Bengkulu Fakultas Ekonomi Manajemen sebesar 0.142 dengan asumsi variabel harga, ulasan produk, kemudahan penggunaan, dan keamanan transaksi. 
4. Koefisien regresi variabel kemudahan penggunaan $\left(X_{3}\right)$ sebesar 0.117 mempunyai makna bahwa apabila kemudahan penggunaan $\left(X_{3}\right)$ ditingkatkan satu satuan, maka akan meningkatkan keputusan pembelian (Y) pada mahasiswa Universitas Muhammadiyah Bengkulu Fakultas Ekonomi Manajemen sebesar 0.117 dengan asumsi variabel harga, ulasan produk, kemudahan penggunaan, dan keamanan transaksi.

5. Koefisien regresi variabel keamanan transaksi $\left(X_{4}\right)$ sebesar 0.344 mempunyai makna bahwa apabila keamanan transaksi $\left(X_{4}\right)$ ditingkatkan satu satuan, maka akan meningkatkan keputusan pembelian ( $\mathrm{Y}$ ) pada mahasiswa Universitas Muhammadiyah Bengkulu Fakultas Ekonomi Manajemen sebesar 0.344 dengan asumsi variabel harga, ulasan produk, kemudahan penggunaan, keamanan transaksi.

Hipotesis Parsial (t)

Uji hipotesis ini dimaksudkan untuk mengetahui seberapa jauh pengaruh satu variabel independen (harga, ulasan produk, kemudahan penggunaan dan keamanan transaksi) secara individual dalam menerangkan variabel dependen (keputusan pembelian). Hasil uji t pada penelitian ini dapat dilihat pada tabel :

Tabel 5. Uji T (Uji Secara Parsial)

Coefficients $^{\mathrm{a}}$

\begin{tabular}{|c|c|c|c|c|c|}
\hline \multirow[b]{2}{*}{ Model } & \multicolumn{2}{|c|}{ Unstandardized Coefficients } & \multirow{2}{*}{$\begin{array}{c}\text { Standardized Coefficients } \\
\text { Beta }\end{array}$} & \multirow[b]{2}{*}{$\mathrm{t}$} & \multirow[b]{2}{*}{ Sig. } \\
\hline & B & Std. Error & & & \\
\hline (Constant) & .632 & 3.175 & & .199 & .843 \\
\hline Harga & 201 & .099 & $.1 \varepsilon$ & 2.022 & .046 \\
\hline Ulasanproduk & .142 & .064 & $.2 C$ & 2.212 & .029 \\
\hline Kemudahan penggunaan & .117 & .055 & .19 & 2.113 & .037 \\
\hline Keamanantransaksi & .344 & .116 & .27 & 2.955 & .004 \\
\hline
\end{tabular}

a. Dependent Variable: keputusanpembelian

Sumber : Hasil Penelitian SPSS 2019

\section{Hipotesis Simultan (F)}

Uji F digunakan untuk menguji ada tidaknya pengaruh variabel-variabel independen terhadap variabel dependen secara simultan (bersama-sama). Adapun hasil perhitungan uji f sebagai berikut.

Tabel 4.5 Uji F (Uji secara simultan)

ANOVA $^{b}$

\begin{tabular}{|l|l|r|l|l|l|l|}
\hline \multicolumn{2}{|c|}{ Model } & Sum of Squares & Df & \multicolumn{1}{|c|}{ Mean Square } & F & Sig. \\
\hline \multirow{2}{*}{1} & Regression & 173.662 & 4 & 43.415 & 6.392 & $.000^{\mathrm{a}}$ \\
\cline { 2 - 8 } & Residual & 679.253 & 100 & 6.793 & & \\
\cline { 2 - 7 } & Total & 852.914 & 104 & & & \\
\hline
\end{tabular}

a. Predictors: (Constant), keamanantransaksi, Harga, kemudahanpenggunaan, ulasanproduk

b. Dependent Variable: keputusanpembelian

Sumber : Hasil Penelitian SPSS 2019 


\section{Pembahasan}

Berdasarkan hasil penelitian dan pengolahan data mentah yang di lakukan pada Mahasiswa/i di Universitas Muhammadiyah Bengkulu Prodi Ekonomi Manajemen, melalui penyebaran kuesioner terhadap 105 orang responden yang telah diuji sehingga dapat diketahui pengaruh Harga, Ulasan Produk, Kemudahan Penggunaan dan Keamanan Transaksi terhadap Keputusan Pembelian Online di Shopee :

1. Pengaruh Harga $\left(X_{1}\right)$ terhadap Keputusan Pembelian ( $Y$ ) harga memiliki pengaruh terhadap keputusan pembelian. Hal ini terlihat pada uji yang menyatakan memiliki nilai $t_{h i t}>t_{a / 2}(2.022>1.982)$ dan (sig $\left.a=0.046<0.050\right)$, maka $\mathrm{H}_{1}$ dalam penelitian ini dapat di terima. Hal ini didukung dengan hasil penelitian yang dilakukan oleh Lenggang Kurnia Intan Devi Nim : g73215037 (2018), Universitas Negri Sunan Apel Surabaya dengan hasil Harga berpengaruh signifikan secara parsial. Penelitian ini juga didukung oleh pendapat menurut Kotler dan Keller (2009) yang mengasumsikan bahwa alasan paling sederhana dari pembelian secara online adalah untuk menghemat uang.

2. Pengaruh Ulasan Produk $\left(\mathrm{X}_{2}\right)$ terhadap Keputusan Pembelian $(\mathrm{Y})$ ulasan produk memiliki pengaruh terhadap keputusan pembelian. Hal ini terlihat pada uji yang menyatakan memiliki nilai yaitu $t_{h i t}>t_{a / 2}(2.212>1.982)$ dan (sig $a=0.029<$ 0.050), maka $\mathrm{H}_{2}$ dalam penelitian ini dapat di terima. Hasil ini didukung oleh pendapat yang dikemukakan oleh business2community.com, ada beberapa alasan kenapa ulasan online itu penting bagi sebuah bisnis online. Pertama adalah bahwa ulasan dapat meningkatkan penjualan. Menurut data dari Reevoo yang dilaporkan econsultancy.com, adanya ulasan dapat meningkatkan rata-rata 18 persen penjualan. Ulasan juga membuat ranking situs akan meningkat di pencarian, semakin tinggi rangking yang didapat maka akan semakin tinggi kesempatannya untuk muncul di halaman pertama pencarian dan akan mempermudah produsen dan konsumen.

3. Kemudahan Penggunaan $\left(X_{3}\right)$ terhadap Keputusan Pembelian ( $Y$ ) kemudahan penggunaan memiliki pengaruh terhadap keputusan pembelian. Hal ini terlihat pada uji yang menyatakan memiliki nilai yaitu $t_{h i t}>t_{a / 2}(2.113>1.982)$ dan (sig $a$ $=0.037<0.050)$, maka $\mathrm{H}_{3}$ dalam penelitian ini dapat di terima. Hasil ini didukung oleh hasil penelitian Fransiska Vania Sudjatmika (2002) Program Manajemen Bisnis, Program Studi Manajemen, Universitas Kristen Petra Jl. Siwalankerto 121-131, Surabaya E-mail: fransiska_vs@ymail.com dengan hasil penelitian yang menyatakan bahwa kemudahan berpengaruh signifikan secara parsial dan simultan.

4. Keamanan Transaksi $\left(\mathrm{X}_{4}\right)$ terhadap Keputusan Pembelian (Y) keamanan transaksi memiliki pengaruh terhadap keputusan pembelian. Hal ini terlihat pada uji yang menyatakan memiliki nilai yaitu $t_{h i t}>t_{a / 2}(2.955>1.982)$ dan (sig $a$ $=0.004<0.050$ ), maka $\mathrm{H}_{3}$ dalam penelitian ini dapat di terima. Hasil ini didukung oleh hasil penelitian Cicilia Desy Widya Permatasari Universitas Dian Nuswantoro (2015) dengan hasil penelitian yang menyatakan bahwa keamanan transaksi berpengaruh signifikan secara parsial dan simultan._Sesuai juga dengan hasil penelitian dari Rachamita Resti Hidayah 2018 yang berjudul Pengaruh Kepercayaan, Kemudahan, Dan Keamanan Terhadap Keputusan Pembelian Pada Situs E-Marketplace mengatakan bahwa Keamanan 
berpengaruh positif dan signifikan terhadap keputusan pembelian. Rsquare sebesar $19,1 \%$.

Pengaruh harga, ulasan produk, kemudahan penggunaan dan keamanan transaksi terhadap keputusan pembelian online di Shopee. Harga $\left(X_{1}\right)$, Ulasan Produk $\left(X_{2}\right)$, Kemudahan Penggunaan $\left(X_{3}\right)$ dan Keamanan Transaksi $\left(X_{4}\right)$ memiliki pengaruh terhadap Keputusan Pembelian ( $Y$ ). Hal ini terlihat pada uji $F$ yang menyatakan nilai $t_{\text {hitung }}>t_{\text {tabel, }}$ yaitu $(6.392>2.69)$ dan ( $\operatorname{sig} a=0.000<0.05$ ) maka dengan demikian dapat disimpulkan bahwa $\mathrm{H}_{5}$ diterima artinya secara bersamaan variabel Harga $\left(X_{1}\right)$, Ulasan Produk $\left(X_{2}\right)$, Kemudahan Penggunaan $\left(X_{3}\right)$ dan Keamanan Transaksi $\left(\mathrm{X}_{4}\right)$ memiliki pengaruh terhadap Keputusan Pembelian ( $\mathrm{Y}$ ) online di Shopee.

\section{KESIMPULAN DAN SARAN}

\section{Kesimpulan}

1. Harga berpengaruh positif dan signifikan secara parsial terhadap keputusan pembelian online di Shopee, hal ini dibuktikan dengan hasil uji t yang menunjukkan nilai yaitu $t_{\text {hit }}>t_{a / 2}(2.022>0.1982)$ dan (sig $\left.a=0.046<0.050\right)$, ini berarti $\mathrm{H}_{0}$ ditolak dan $\mathrm{H}_{a}$ di terima.

2. Ulasan Produk berpengaruh positif dan signifikan secara parsial terhadap keputusan pembelian online di Shopee, hal ini dibuktikan dengan hasil uji t yang menunjukkan nilai yaitu $t_{h i t}>t_{a / 2}(2.212>0.1982)$ dan (sig $a=0.029<$ 0.050), ini berarti $\mathrm{H}_{0}$ ditolak dan $\mathrm{H}_{\mathrm{a}}$ di terima.

3. Kemudahan Penggunaan berpengaruh positif dan signifikan secara parsial terhadap keputusan pembelian online di Shopee, hal ini dibuktikan dengan hasil uji t yang menunjukkan nilai yaitu $t_{h i t}>t_{a / 2}(2.113>0.1982)$ dan (sig $a=$ $0.037<0.050)$, ini berarti $\mathrm{H}_{0}$ ditolak dan $\mathrm{H}_{\mathrm{a}}$ di terima.

4. Keamanan Transaksi berpengaruh positif dan signifikan secara parsial terhadap keputusan pembelian online di Shopee, hal ini dibuktikan dengan hasil uji t yang menunjukkan nilai yaitu $t_{h i t}>t_{a / 2}(2.955>0.1982)$ dan (sig $a=$ $0.004<0.050)$, ini berarti $\mathrm{H}_{0}$ ditolak dan $\mathrm{H}_{a}$ di terima.

5. Harga $\left(X_{1}\right)$ Ulasan Produk $\left(X_{2}\right)$, Kemudahan Penggunaan $\left(X_{3}\right)$ dan Keamanan Transaksi $\left(X_{4}\right)$ secara bersama-sama berpengaruh terhadap Keputusan Pembelian ( $Y$ ) online di Shopee, hal ini dibuktikan dengan uji F menunjukkan

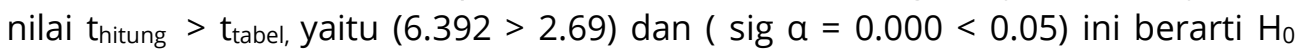
ditolak dan $\mathrm{H}_{a}$ diterima .

6. Berdasarkan uji koefisien korelasi didapat nilai $\mathrm{R}=0.421$ dan koefisien determinasi $R^{2}=0.204$ nilai ini mempunyai makna bahwa Harga $\left(X_{1}\right)$, Ulasan Produk $\left(X_{2}\right)$, Kemudahan Penggunaan $\left(X_{3}\right)$, Keamanan Transaksi $\left(X_{4}\right)$ memberikan kontribusi pengaruh sebesar 0.203 atau $20.3 \%$ terhadap Keputusan Pembelian online di Shopee (Y) pada mahasiswa Universitas Muhammadiyah Bengkulu Prodi Ekonomi Manajemen dan sisanya (100 - 20,3\% $=79.7 \%$ ) di pengaruhi oleh variabel lain .

\section{Saran}

1. Harga, ulasan produk, kemudahan penggunaan, dan keamanan transaksi, merupakan faktor yang diperlukan dalam meningkatkan Keputusan Pembelian maka perlu saling dukung dalam kegiatan pembelian online di Shopee pada 
mahasiswa Universitas Muhammadiyah Bengkulu Fakultas Ekonomi Manajemen. harus lebih meningkat lagi serta perlunya memperhatikan kemudahan penggunaan yang baik, guna untuk mencapai tujuan yang akan ditetapkan oleh pembelian online di Shopee terutama untuk menarik minat mahasiswa baru sebanyak mungkin dengan memperbaiki server supaya situs tidak error apabila diakses oleh banyak orang, menambah cara pembayaran supaya pembeli bisa membeli dengan mudah, mempermudah cara pembatalan pembelian produk, dan lain sebagainya.

2. Sesuai dengan hasil deskriptif responden yang menyatakan bahwa mayoritas pengguna Shopee yang berumur relatif muda dan berprofesi sebagai pelajar atau mahasiswa, pihak Shopee sebaiknya lebih memperhatikan faktor harga dengan cara melakukan lebih banyak program diskon atau program gratis ongkir pada pelanggan tanpa harus membeli dalam kuantitas banyak atau melakukan deposit saldo di Shopee. Program gratis ongkir sebaiknya dilakukan dengan minimal pembelanjaan yang tidak terlalu tinggi, contohnya Rp 100.000. Hal ini disarankan supaya semakin banyak orang yang tertarik untuk membeli produk melalui Shopee.

3. Keamanan transaksi merupakan faktor yang paling berpengaruh dalam pengambilan keputusan memilih berbelanja, hal ini menunjukkan bahwa konsumen sangat peka terhadap keamanan transaksi sehingga sebaiknya pembelian online di Shopee mempertahankan sistem keamanan transaksi yang sudah ada. Keamanan dalam melakukan transaksi online merupakan hal utama yang diinginkan oleh pembeli. Dalam hal ini, pihak Shopee harus dapat menjamin keamanan pembeli saat berbelanja di situsnya. Shopee.com harus dapat mempertahankan atau meningkatkan kualitas keamanannya baik dalam hal kerahasiaan data pelanggan maupun informasi, sistem verifikasi atau autentifikasi.

\section{DAFTAR PUSTAKA}

Admin. https://shopee.co.id/KategoriProduk, diakses 10 Maret 2018.

Aladwani, A. M. (2002). The development of two tools for measuring the easiness and usefulness of transactional Web sites. European Journal of

Armstrong, dan Kotler 2015, "Marketing an IntroducingPrentice Hall twelfth edition", England: Pearson Education, Inc

Bailey, J. E. dan Pearson, S. W. 1983. Development of a tool for measuring dan analyzing computing user satisfaction. Management Science 29(5): 540-545.

Bambang pranoto. 2008. Pengaruh Harga dan Kualitas Produk Terhadap Keputusan Konsumen Membeli Kendaraan Bermotor, Jurnal IImiah Faktor Extra Vol.1 No. 2 September 2008.

Basu Swastha \& Irawan. 2005. Manajemen Pemasaran Modern. Liberty, Yogyakarta. Cheung, Christy M.K and Dimple R. Thadani.2010.The Effectiveness of Electronic Word-of-Mouth Communication: A Literature Analysis. Implications for the Individual, Enterprises and Society

Cooper, Donal R and Scindler, Pamela S (2006). Busines Research Methods. The MC Grow-Hill Lumpanies: Singapore. 
Davis, A., and Khazanchi, D., 2008, An empirical study of online word of mouth as apredictor for multi-product category e-commerce sales, Electronic Markets, vol 18no 2, 130-141

Elliot, S., \& Fowel, S. (2000). "Expectations versus reality: A Snapshot of Consumer experiences with internet retailing". International Journal of Information Management, Vol 20: 323-336.

Engel, J. F. 2001. Perilaku Konsumen. Jakarta: Penerbit Binarupa Aksara

Gauzente, C. (2004). "Web merchant's privacy and security statement: How reassuring are they customers? Two sided approach", Journal of Electronic Commerce Research. Vol 5 (3): 181-198.

Ghozali, Imam. (2011). Aplikasi Analisis Multivariate Dengan Program IBM SPSS 19 (edisi kelima.) Semarang: Universitas Diponegoro.

Igbraria, M.A. Chakrabarti. (2000). Computer Anxiety and Attitudes Towards Microcomputer Use. Behaviour Inform. Tech. Vol 9 No 3 Hal 229-241.

Jogiyanto. (2007). Sistem Informasi Keperilakuan. Yogyakarta: Andi Yogyakarta.

Katawetawaraks, C. \& Cheng, L. W. (2011). Online shopper behavior: Influences of online shopping decision. Asian Journal of Business Research, 1 (2), 66-74.

Kim T.W., Seo J.N., Suh Y.H., Park H.J., Kim J.H., Kim J.Y.et al. 2006. Involvement of lymphocytes in dextran sulfate sodium-induced experimental colitis. World J.Gastroenterol.12(2): 302-305

Kotler dan Keller. 2009. Manajemen Pemasaran. Jilid I. Edisi ke 13 Jakarta: Erlangga.

Kotler, Amstrong. 2001. Prinsip-prinsip pemasaran, Edisi keduabelas, Jilid 1. Jakarta: Erlangga

Kotler, Philip \& Gary Armstrong. (2004). "Principles of Marketing". 10th Ed. New Jersey: Pearson Prentice Hall.

Kotler, Philip; Armstrong, Garry, 2008. Prinsip-prinsip Pemasaran, Jilid 1, Erlangga, Jakarta.

Lackermair, G, D. Kailer and K, Kanmaz, (2013), Importance Of Online Product Reviews From A Consumer's Perspective, 1(1), pp.1-5.

Liao, Z., \& Cheung, M. T. (2001). "Internet based e-shopping and consumer attitudes: An Empirical Study". Information Management, 38, 299-306.

Longenecker, Justin G., dkk, Kewirausahaan: Manajemen Usaha Kecil, Jakarta: Salemba Empat, 2001.

Luo, et al., 2014. Chemical Composition and In Vitro Evaluation of The Cytotoxic and Antioxidant Activities of Supercritical Carbon Dioxide Extracts of Pitaya (Dragon Fruit) Peel. Chemistry central journal. China.

Maholtra, N. K., Kim, S. S., \& Agarwal, J. (2004). "Internet users' information privacy concern (IUIPC). The construct the scale, and a causal model".Information System Research, 15 (4), 336-355.

Mangold, W. G., \& Smith, K. T. (2012). Selling to Millennials with Online Reviews. Business Horizons, 55 (2), 141-153. http://dx.doi:10.1016/j.bushor.2011.11.00

McCarthy, Jerome, E.; Perreault, William D, 2003. Dasar-dasar Pemasaran, Edisi kelima, alih Bahasa : Agus Darma. Jakarta : Erlangga.

Nurzam, N., Fauziah, R. S., \& Susena, K. C. (2020). Pegaruh Harga Dan Kualitas Produk Terhadap Keputusan Petani Membeli Bibit Sawit Di PT. Bio Nusantara Teknologi Bengkulu. EKOMBIS REVIEW: Jurnal IImiah Ekonomi dan Bisnis, 8(1), 79-89. 
Paul, Peter. J dan Jerry C. Olson, 2000, Consumer Behaviour : Perilaku Konsumen dan Strategi Pemasaran, jilid 1 dan jilid 2, Jakarta : Erlangga. Rahmatunnisa, M. Jurnal bawaslu ISSN 2443-2539. Vol. 3 No. 1 2017, Hal. 1-11

Rachmatunnisa. (2016, August 24). Pengguna internet Indonesia naik signifikan tapi, Detikcom. Retrieved September 3, 2016, from http://inet.detik.com/read/2016/08/24/192005/3282786/398/pengguna internet-indonesia-naik-signifikan-tapi.

Raman, Arasu., \& Viswanathan, A. (2011). "Web Services and e-Shopping Decisions: A Study on Malaysian e-Consumer". IJCA Special Issue on: Wireless Information Networks \& Business Information System, hal.54-60.

Schiffman dan Kanuk. 2008. Perilaku konsumen. Edisi 7. Jakarta: Indeks

Setiadi, N.J. 2003. Perilaku Konsumen : Konsep dan Implikasi Untuk Strategi dan Penelitian Pemasaran. Jakarta : Kencana.

Shanthi, R., and Desti Kannaniah. (2015). Consumers' Perception on Online Shopping. Journal of Marketing and Consumer Research An International Peer-

reviewed Journal Vol. 13. Retrieved September 17, 2016, from http://researchonline.jcu.edu.au/39753/1/Dr.\%20Desti\%20Consumers\%20 perception\%20on\%20Online\%20Shop ping.pdf.

Simamora Bilson, 2003, Memenangkan Pasar dengan Pemasaran Efektif \& Profitabel, Gramedia Pustaka Utama, Jakarta.

Singgih Santoso (2015). Panduan lengkap menguasai statistika dengan spss17.Elex Media Komputindo.

Stanton, William J (Swasta \& Handoko). 2008. Manajemen Pemasaran, Analisis Perilaku Konsumen http://library.um.ac.id (diakses tanggal 11 November 2012 pukul 14.00).

Sugiyono. 2010. Metode Penelitian Pendidikan Pendekatan Kuantitatif, kualitatif, dan $R \& D$. Bandung : Alfabeta

Susena, K. C., Irwanto, T., \& Priandi, E. (2019). Faktor-Faktor Yang Mempengaruhi Keputusan Nasabah Dalam Memilih Pembiayaan Griya Ib Hasanah Di PT. Bank Bni Syariah Kantor Cabang Bengkulu. EKOMBIS REVIEW: Jurnal IImiah Ekonomi dan Bisnis, 7(2).

Swastha, Basu dan Irawan. 1997. Manajemen Pemasaran Modern. Cetakan Kelima.Yogyakarta : Liberty.

Sweeney, J. And Soutar, G. 2001. "Consumer perceived value: the development of a multiple item scale". Journal of Retailing, Vol. 77, pp. 203-205.

Szymanski, D. M., \& Hise, R. T. (2000). "E-Satisfaction: An initial examination. Journal of Retailing". 76 (3). 309-322. 